\title{
Determination of Selected Heavy Metals in the Organs of Some Animals Reared in the Gold-Mining Areas of Zamfara State, Nigeria
}

\author{
U. A. Birnin-Yauri ${ }^{*}$, M. K. Musa1 ${ }^{1}$, S. M. Alhaji ${ }^{2}$ \\ ${ }^{1}$ Department of Pure and Applied Chemistry, Usmanu Danfodiyo University, Sokoto, Nigeria \\ ${ }^{2}$ Department of Chemistry, Sokoto State University, Sokoto, Nigeria \\ Email: *uabyauri@gmail.com
}

How to cite this paper: Birnin-Yauri, U.A., Musa, M.K. and Alhaji, S.M. (2018) Determination of Selected Heavy Metals in the Organs of Some Animals Reared in the Gold-Mining Areas of Zamfara State, Nigeria. Journal of Agricultural Chemistry and Environment, 7, 188-202.

https://doi.org/10.4236/jacen.2018.74016

Received: March 25, 2018

Accepted: November 26, 2018

Published: November 29, 2018

Copyright $\odot 2018$ by authors and Scientific Research Publishing Inc. This work is licensed under the Creative Commons Attribution International License (CC BY 4.0).

http://creativecommons.org/licenses/by/4.0/

\begin{abstract}
The study was conducted to determine the concentrations of heavy metals $(\mathrm{Cu}, \mathrm{Zn}, \mathrm{Co}, \mathrm{Mn}, \mathrm{Fe}, \mathrm{Cr}, \mathrm{Cd}$ and $\mathrm{Pb})$ in the liver, kidney and flesh of Cattle, Sheep and Goats from Anka and Bukkuyum Local Government areas of Zamfara State Nigeria. The levels of heavy metals in the liver, kidney and flesh of beef, mutton and caprine ranged from 56 to $549 \mu \mathrm{g} \cdot \mathrm{g}^{-1}$ for $\mathrm{Zn} ; 109$ to $576 \mu \mathrm{g} \cdot \mathrm{g}^{-1}$ for Fe; 0.0 to $4.0 \mu \mathrm{g} \cdot \mathrm{g}^{-1}$ for $\mathrm{Pb} ; 2.52$ to $13.25 \mu \mathrm{g} \cdot \mathrm{g}^{-1}$ for $\mathrm{Mn} ; 0.00$ to $19.64 \mu \mathrm{g} \cdot \mathrm{g}^{-1}$ for Cr; 0.00 to $0.25 \mu \mathrm{g} \cdot \mathrm{g}^{-1}$ for Cd; 0.00 to $2.71 \mu \mathrm{g} \cdot \mathrm{g}^{-1}$ for Co and 3.59 to $538 \mu \mathrm{g} \cdot \mathrm{g}^{-1}$ for $\mathrm{Cu}$. The concentration of $\mathrm{Cr}, \mathrm{Pb}$ and $\mathrm{Mn}$ in the kidneys and livers of the samples were observed to be higher than the maximum allowable level. Similarly, the exception of $\mathrm{Cr}$ in the liver of sheep and goat from Anka and liver of sheep from Bukkuyum, $\mathrm{Pb}$ in some liver and kidney samples and $\mathrm{Mn}$ in some liver, kidney samples and flesh of cattle from Anka were found to be polluted and hence unsafe for consumption.
\end{abstract}

\section{Keywords}

Heavy Metals, Caprine, Mutton, Beef, Environment, Cattle, Sheep, Goats

\section{Introduction}

Heavy metal, is defined as that metal, which is neither essential nor has beneficial effects on the contrary; it displays severe toxicological symptoms at low level and is defined as metal with a density more than $5 \mathrm{~g} / \mathrm{cm}^{3}$. These metals belong to the group of elements described geochemically as trace elements because they are collectively comprised of less than $1 \%$ of the rocks in the earth crust. All trace elements are toxic to living organism in excessive concentrations, but some are essentials for the normal healthy growth and production [1]. 
The presence of heavy metals in the environment has been the subject of public concern in the recent years. Some of these metals are present in low levels in animals and plant tissues where they play great important roles and such categories of heavy metals are also called trace elements. Through human activities the biochemical and geochemical cycles and levels of most heavy metals have been altered. Since they are stable and cannot be degraded, they tend to buildup in the atmosphere, sediments, soil and water. All heavy metals are toxic to living organism at excessive concentrations, even when they are necessary for good health [2] [3] [4].

The risk associated with the exposure to heavy metals present in food products had aroused wide spread concern in human health. Improvement in the food production and processing technology had increased the chances of contamination of food with various environmental pollutants, especially heavy metals.

Ingestion of this contaminant by animals causes deposition of residues in meat. Due to the grazing of cattle on contaminated soils, higher levels of heavy metal have been found in beef and mutton [5]. Although contamination of animals feed by toxic metals cannot be entirely avoided given the prevalence of these pollutants in the environment, there is a clear need for such contamination to be minimized, with the aim of reducing both direct effects on animals health and in direct effects on human health [6]. Toxic effects of metals have been described in animals under relatively low levels of metals exposure [7]; one of the earliest effects is the disruption of trace element metabolism [8] [9].

\subsection{Study Area}

Zamfara state is a state where farming and mining is their major economic activities. This has been confirmed by the passed tragic $\mathrm{Pb}$ pisoning disaster in $\mathrm{Ba}$ gega and Yargalma, where over than 160 Children died after coming in contact with galena polluted ore obtained from gold mining site that was dumped in their compound [10]. The soil in the affected compound was reported to have $\mathrm{Pb}$ levels up to 23 times the maximum acceptable levels in soils sat by USEPA (Figure 1).

\subsection{Sampling}

A total of eighteen meat samples comprising of fresh flesh, kidney and liver of cattle, sheep and goat were collected from Bagega and Anka abattoir in Anka Local Government and also from Yargalma Village, and Masama district abattoir in Bukkuyum Local Government area of Zamfara State, Nigeria. These samples were collected in polyethylene bags and preserved using freezing method and later transported to the laboratory for analysis. All samples were properly cleaned and kept in acid leached nylon bags.

The sample collected were dried in an oven at $105^{\circ} \mathrm{C}$ for $48 \mathrm{hrs}$ to a constant weight and pulverized with a porcelain mortar and pestle and kept in acid nylon bags in a desiccator prior to digestion. 


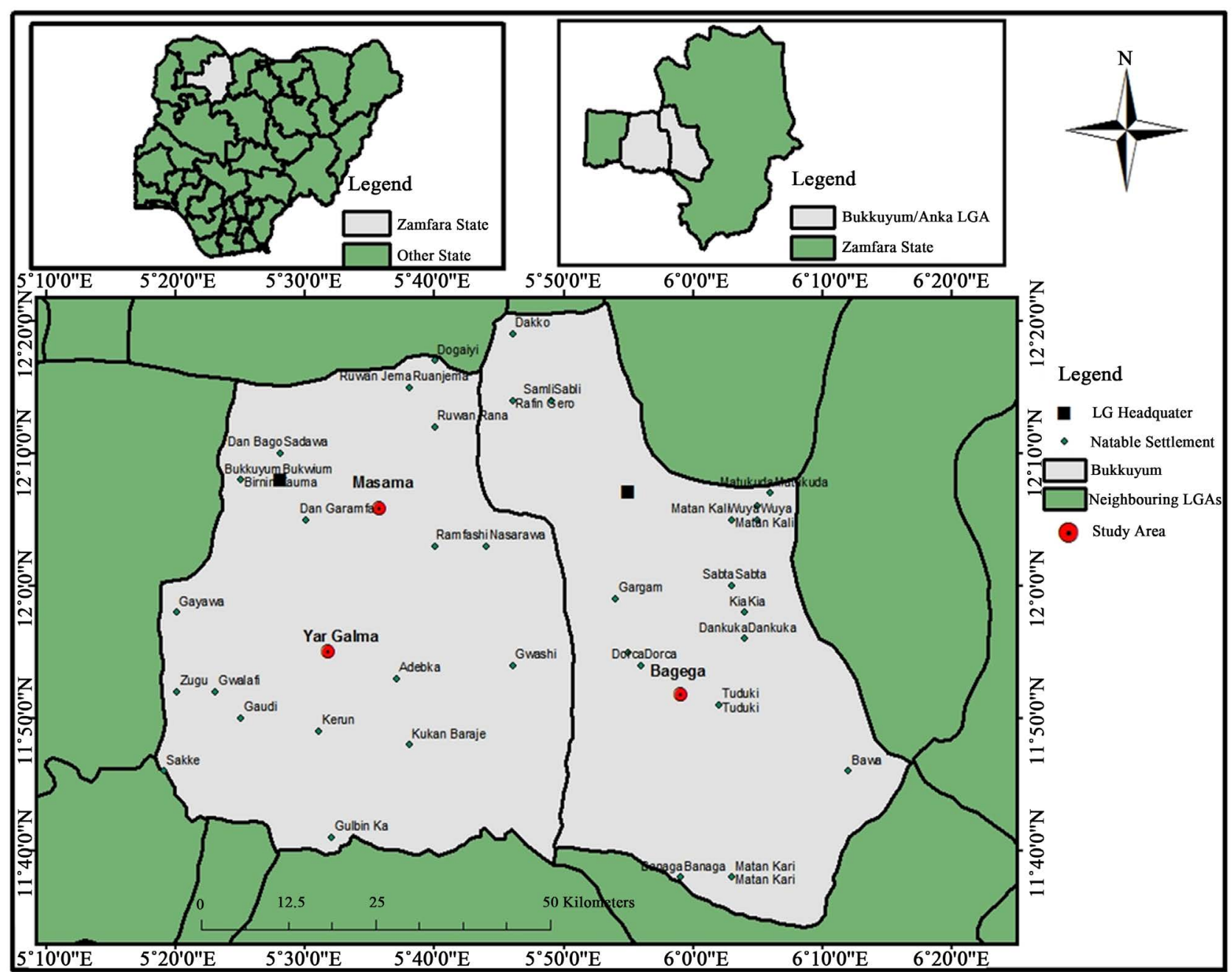

Figure 1. Map of sampling areas.

\subsection{Sample Preparation}

The digestion of the samples was done using a mixture of $\mathrm{HNO}_{3}, \mathrm{HClO}_{4}$ and $\mathrm{H}_{2} \mathrm{O}_{2} .2 .00 \mathrm{~g}$ of each sample was placed in a digestion tube and predigested in $10.0 \mathrm{~cm}^{3}$ concentrated $\mathrm{HNO}_{3}$ at $135^{\circ} \mathrm{C}$ until the liquor was clear. Then, $10.0 \mathrm{~cm}^{3}$ of $\mathrm{HNO}_{3}, 1.0 \mathrm{~cm}^{3} \mathrm{HClO}_{4}$ and $2.0 \mathrm{~cm}^{3} \mathrm{H}_{2} \mathrm{O}_{2}$ were added and temperature was maintained at $135^{\circ} \mathrm{C}$ until the liquor became colorless. The digest was allowed to evaporate to near dryness (avoiding prolong baking), allowed to cool and dissolved in 1.0 $\mathrm{M} \mathrm{HNO}_{3}$. The digest was subsequently filtered through Whatman filter paper No.1 into a $25 \mathrm{~cm}^{3}$ volumetric flask and diluted to the volume with 1.0 $\mathrm{M} \mathrm{HNO}_{3}$ [11]. Heavy metals concentrations were determined using Atomic Absorption Spectroscopy (AAF240).

\subsection{Statistical Analysis}

Data collected were presented as mean and standard deviation and were subjected to one way analysis of variance (ANOVA) to assess whether heavy metals varied significantly between animals. 


\section{Results and Discussion}

Figures 2-17 show the concentrations of heavy metals in the samples. Results of analysis of variance (ANOVA) did not show significant variation in the concentrations of the various metals in the different parts of the animals.

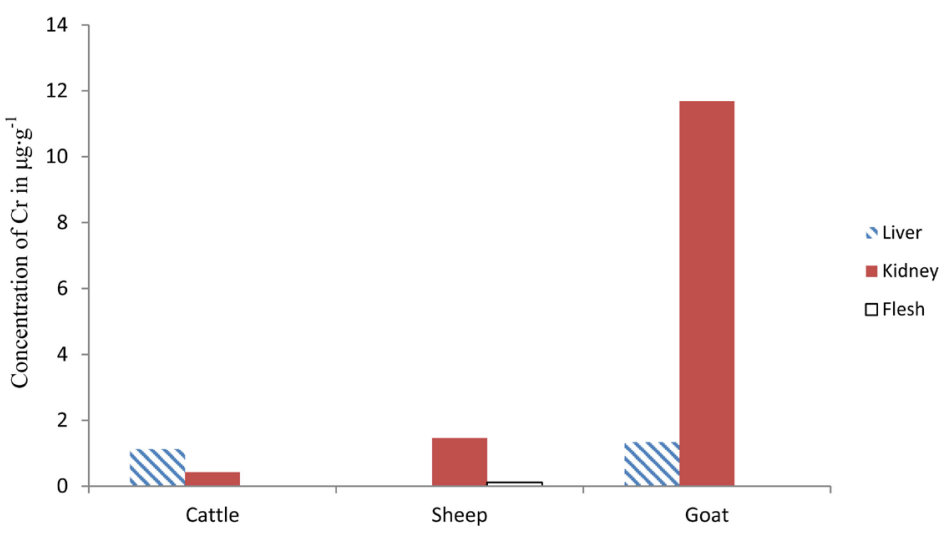

Figure 2. Mean concentration of $\mathrm{Cr}$ in the liver, kidney and flesh of sheep, goat and cattle.

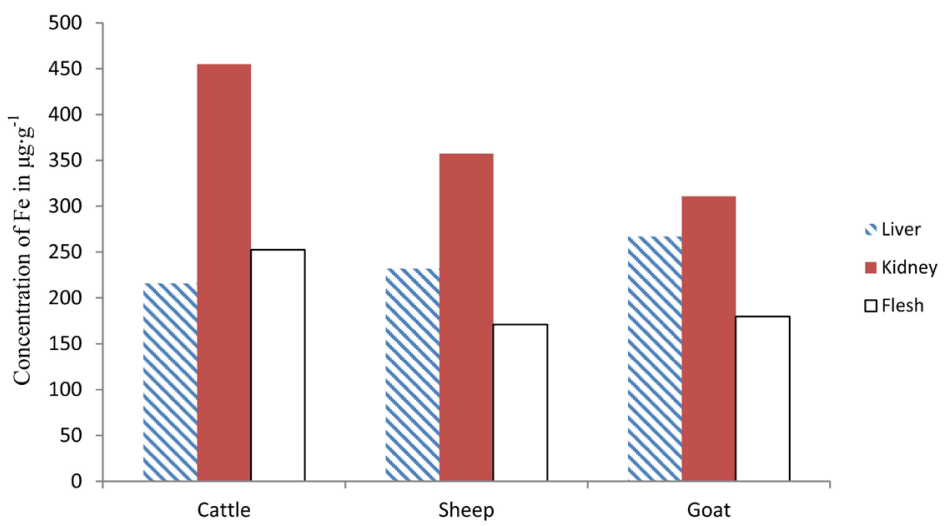

Figure 3. Mean concentration of Fe in the liver, kidney and flesh of sheep, goat and cattle.

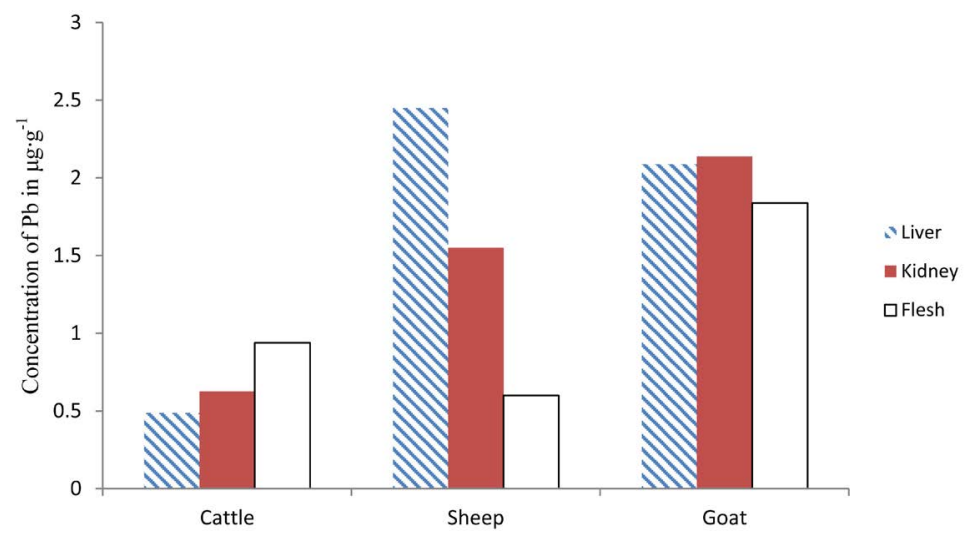

Figure 4. Mean concentration of $\mathrm{Pb}$ in the liver, kidney and flesh of sheep, goat and cattle. 


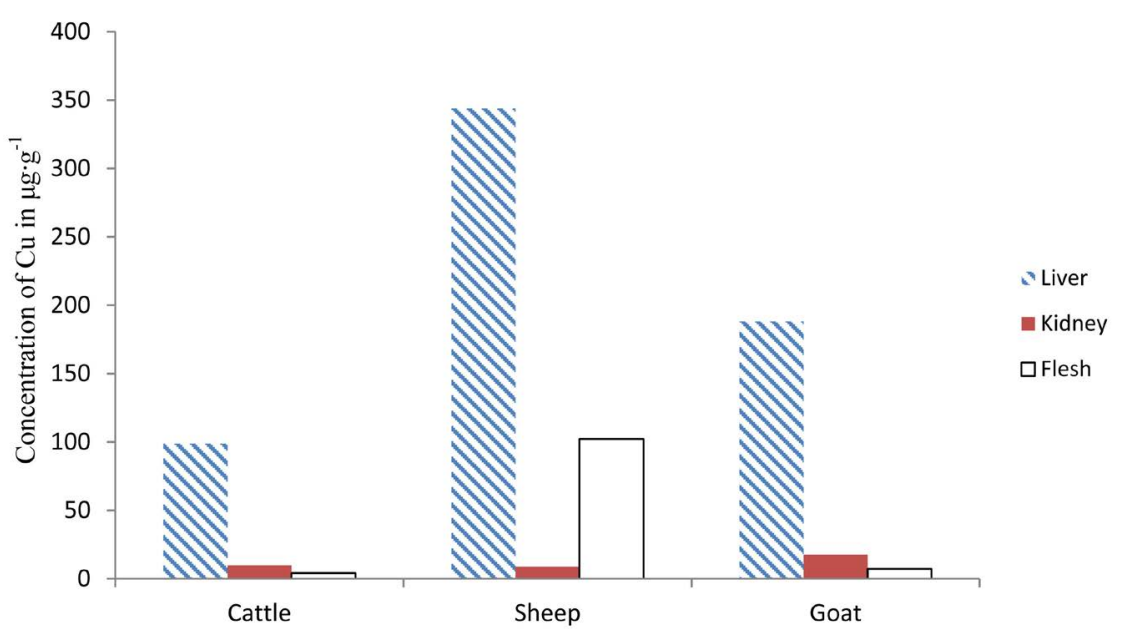

Figure 5. Mean concentration of $\mathrm{Cu}$ in the liver, kidney and flesh of sheep, goat and cattle.

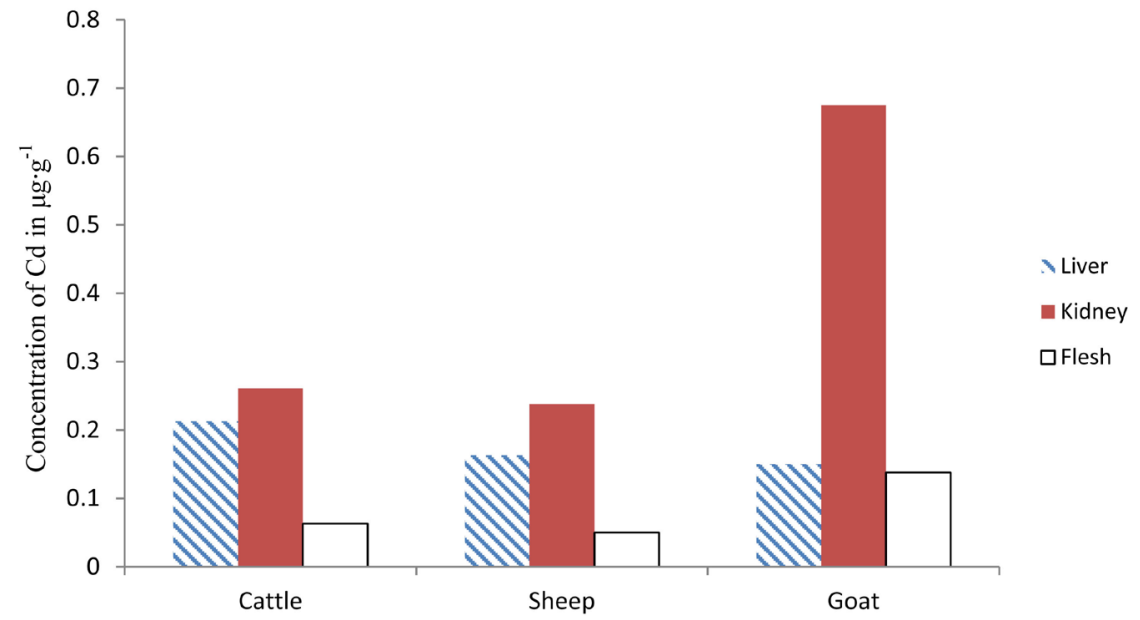

Figure 6. Mean concentration of Cd in the liver, kidney and flesh of sheep, goat and cattle.

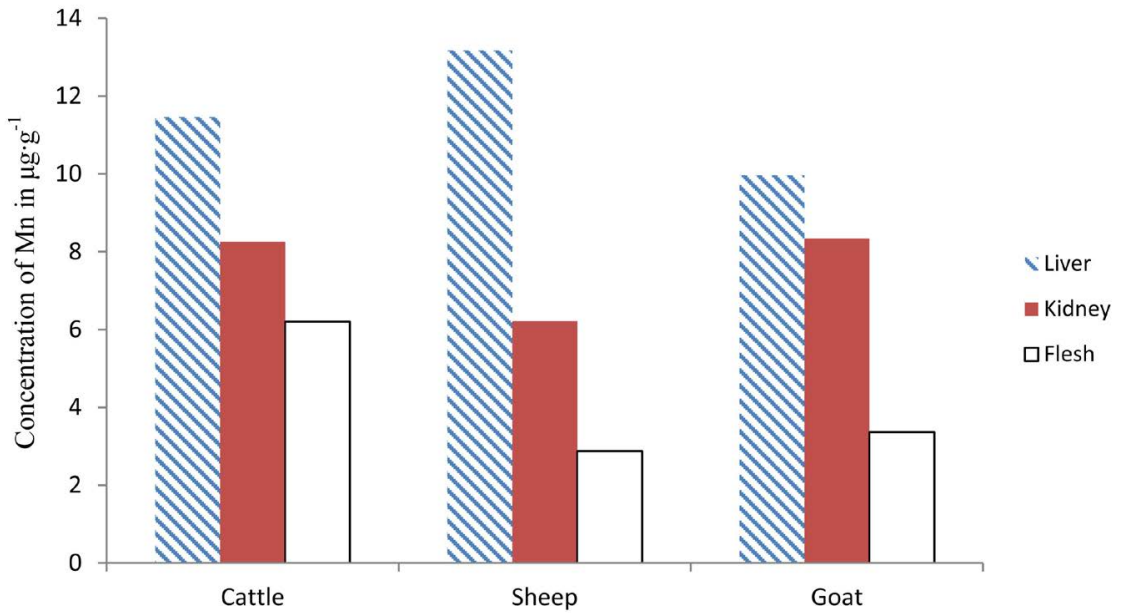

Figure 7. Mean concentration of Mn in the liver, kidney and flesh of sheep, goat and cattle. 


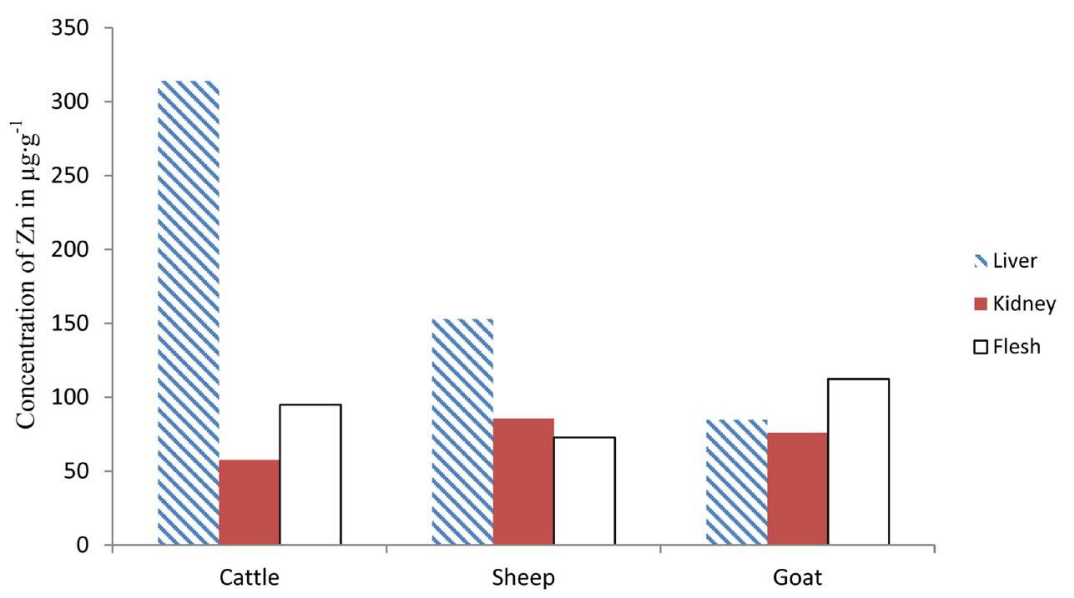

Figure 8. Mean concentration of $\mathrm{Zn}$ in the liver, kidney and flesh of sheep, goat and cattle.

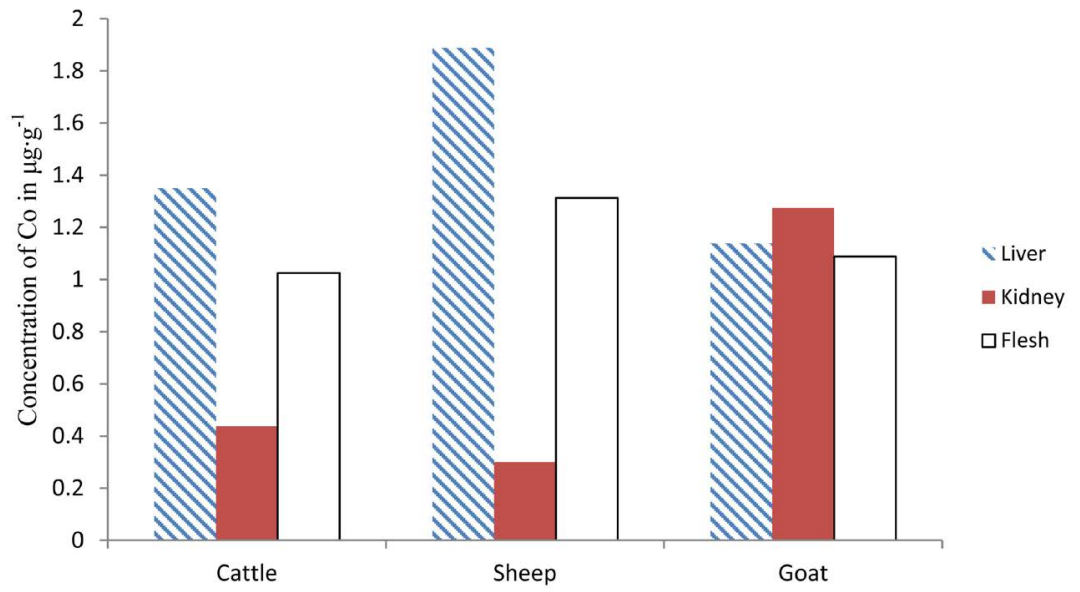

Figure 9. Mean concentration of Co in the liver, kidney and flesh of sheep, goat and cattle.

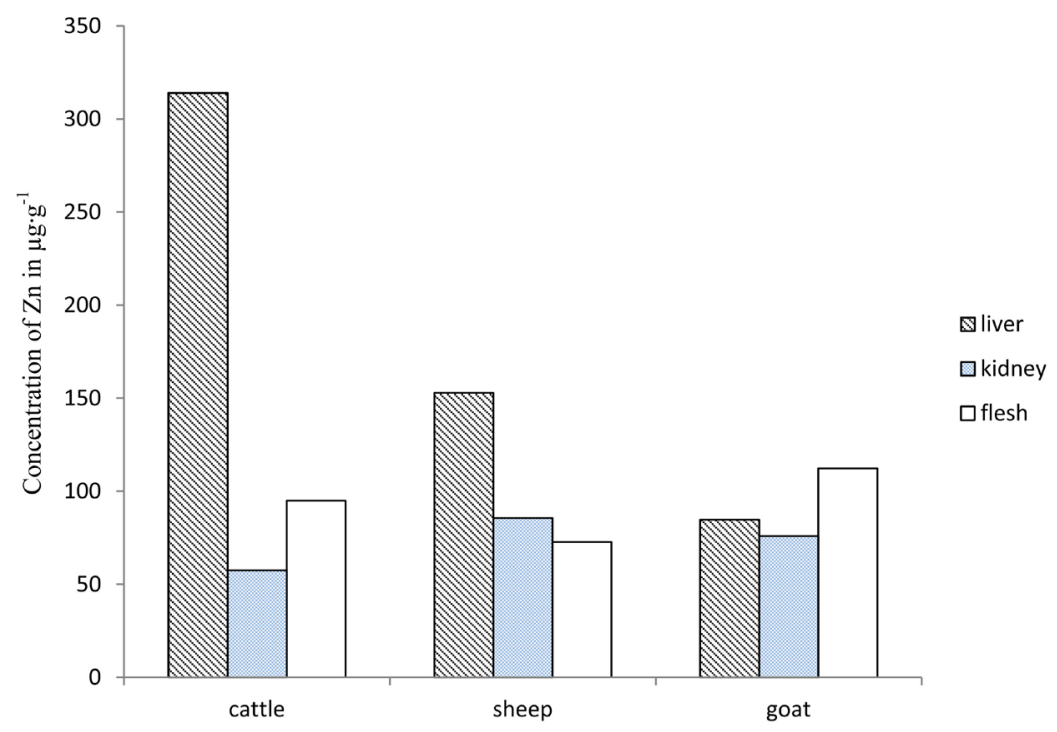

Figure 10. Average concentration $\left(\mu \mathrm{g} \cdot \mathrm{g}^{-1}\right)$ of $\mathrm{Zn}$ in study area. 


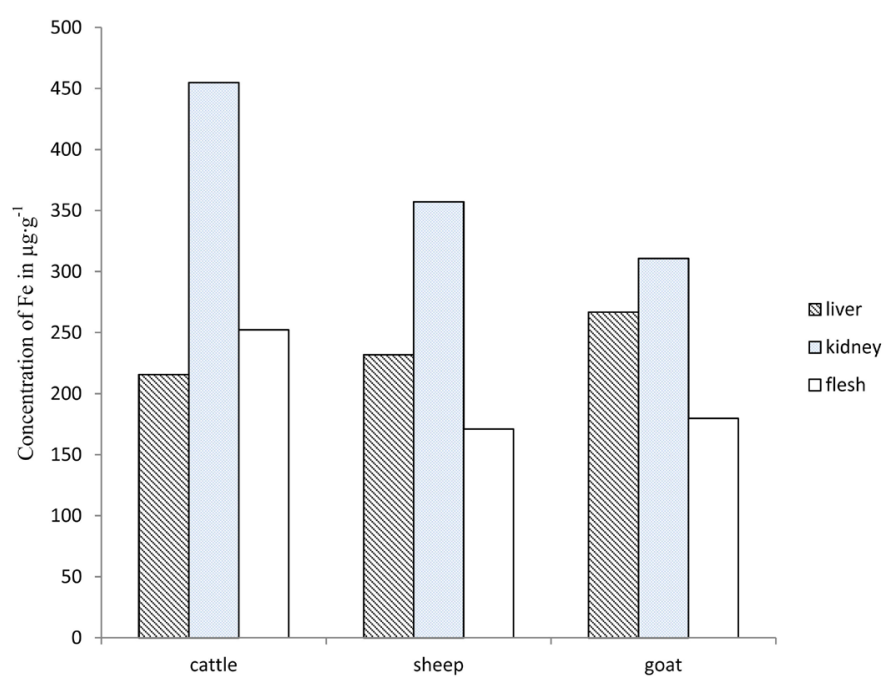

Figure 11. Average concentration $\left(\mu \mathrm{g} \cdot \mathrm{g}^{-1}\right)$ of iron in study area.

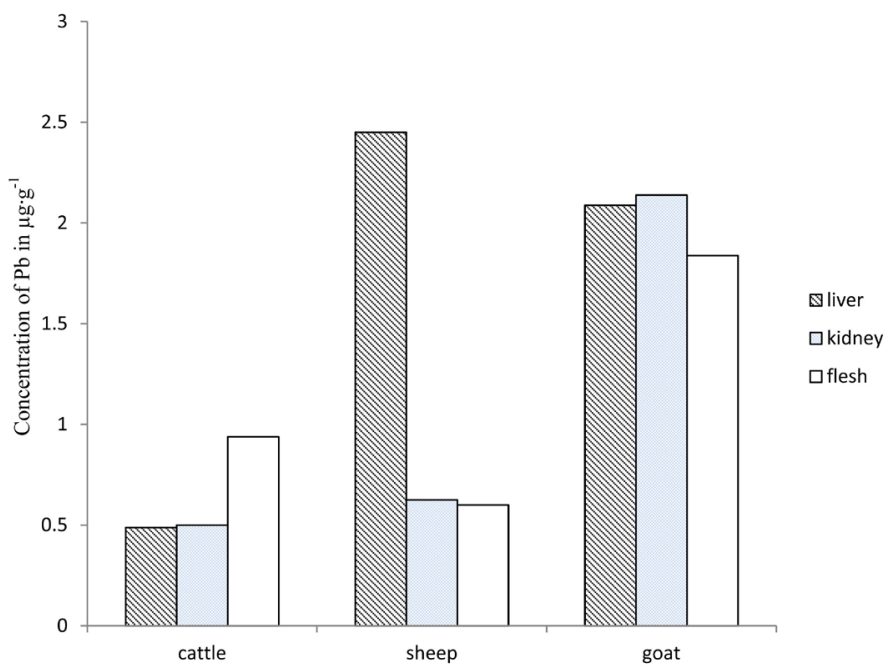

Figure 12. Average concentration $\left(\mu \mathrm{g} \cdot \mathrm{g}^{-1}\right)$ of lead in study area.

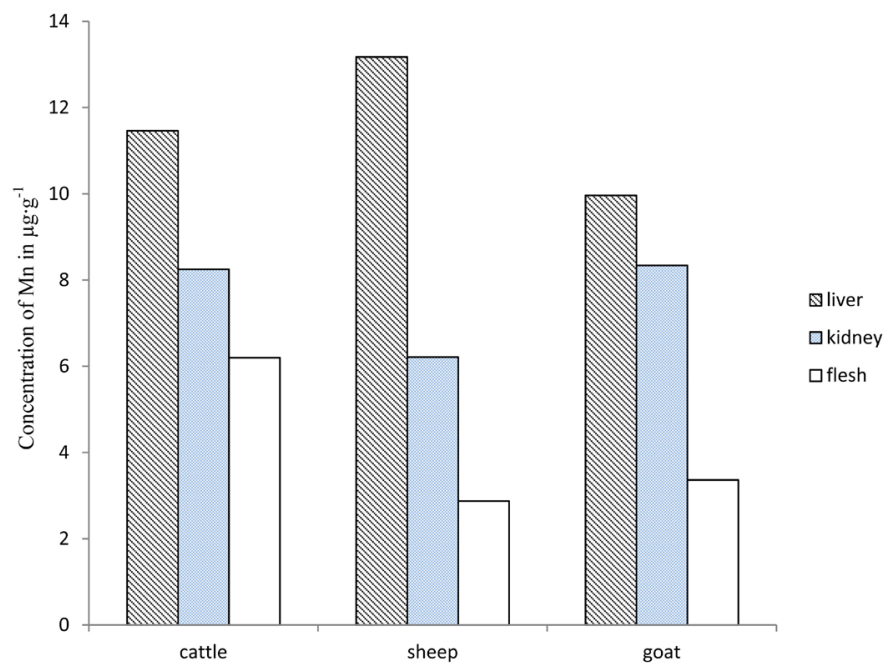

Figure 13. Average concentration $\left(\mu \mathrm{g} \cdot \mathrm{g}^{-1}\right)$ of manganese in study area. 


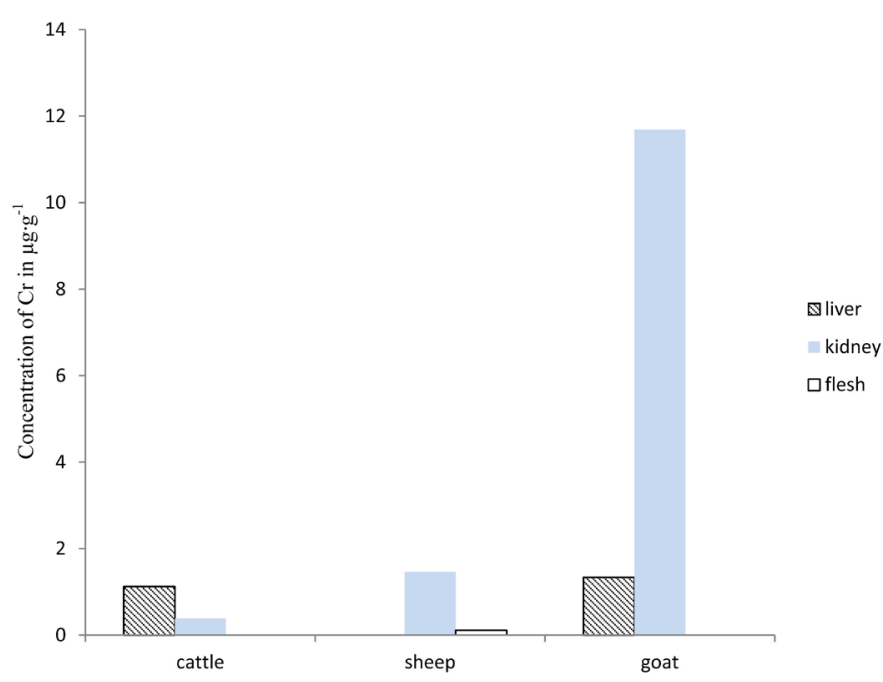

Figure 14. Mean concentration $\left(\mu \mathrm{g} \cdot \mathrm{g}^{-1}\right)$ of chromium in study area.

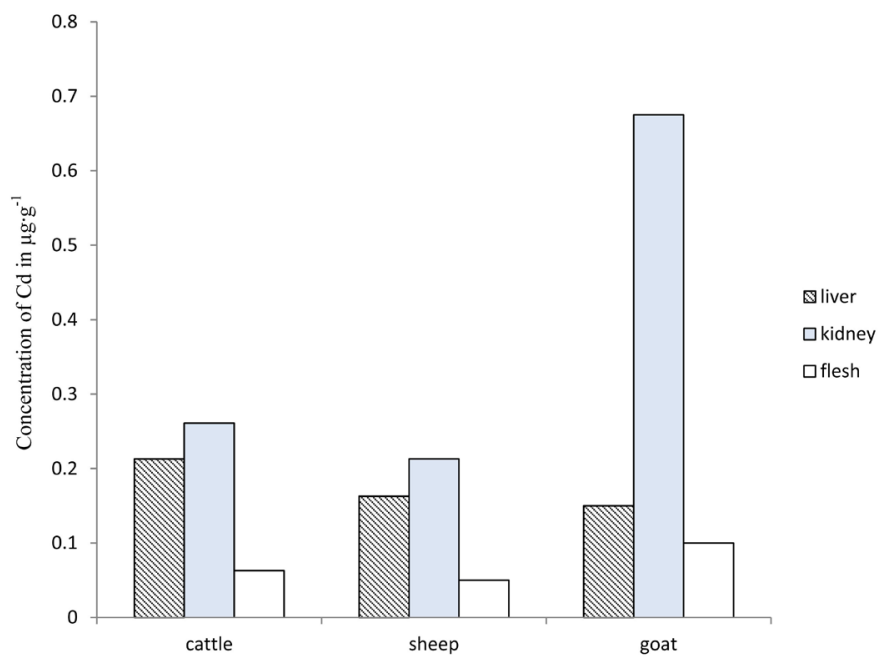

Figure 15. Average concentration $\left(\mu \mathrm{g} \cdot \mathrm{g}^{-1}\right)$ of cadmium.

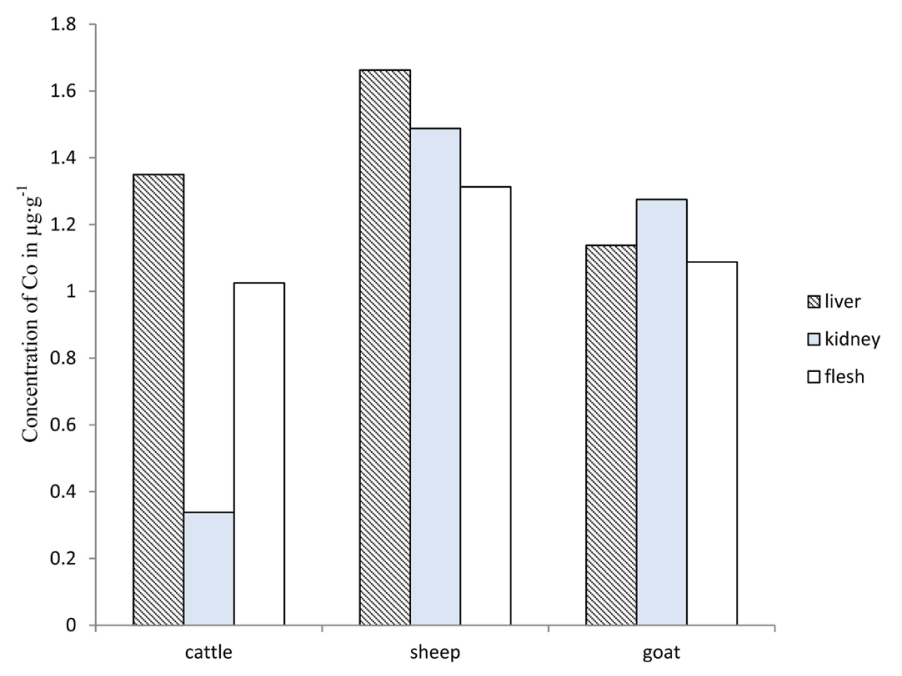

Figure 16. Average concentration $\left(\mu \mathrm{g} \cdot \mathrm{g}^{-1}\right)$ of cobalt in study area. 


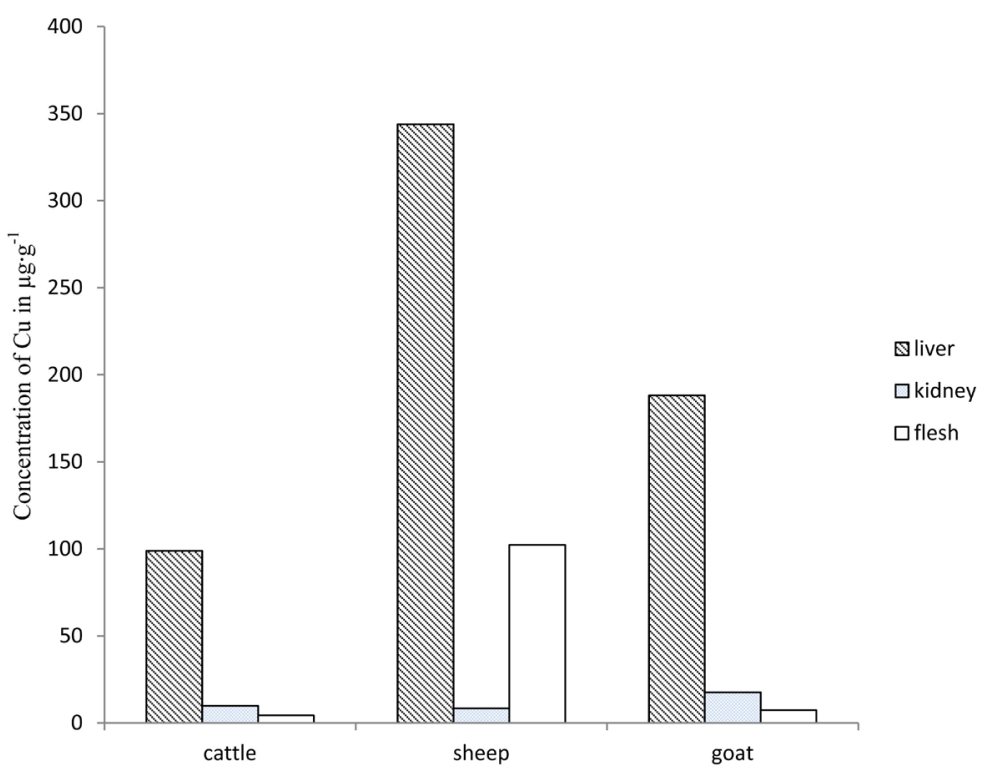

Figure 17. Average concentration $\left(\mu \mathrm{g} \cdot \mathrm{g}^{-1}\right)$ of copper in study area.

\section{Discussions}

\subsection{Level of Chromium [Cr]}

Chromium is an essential element helping the body to use sugar, protein and fat, at the same time it is carcinogenic for organism [12] in excessive amount. The concentration of chromium (Cr) observed in the liver, kidney and flesh of cattle, sheep and goat were presented in Tables 1-6. The highest concentration of $\mathrm{Cr}$ was found in the kidney of goat as presented $19.625 \pm 0.018 \mu \mathrm{g} \cdot \mathrm{g}^{-1}$ and the lowest levels was observed in the flesh of sheep $0.225 \pm 0.010 \mu \mathrm{g} \cdot \mathrm{g}^{-1}$ as indicated in Table 5. The concentration of all the heavy metals in the liver, kidney and flesh samples were higher than the permissible limit of $0.10 \mu \mathrm{g} \cdot \mathrm{g}^{-1}$ set [13] with the exception of 8 samples from Anka and Bukkuyum which included livers and flesh samples where the $\mathrm{Cr}$ was not detected at all. The high concentration of $\mathrm{Cr}$ observed in the kidney of goat may probably be due to the processing of the organ [14]. The results reported by the study were higher than the values $0.27 \pm$ $0.04 \mu \mathrm{g} \cdot \mathrm{g}^{-1}$ recorded by Akan et al. [15] in liver of goat. Similarly the values recorded were not in agreement with the values $0.06 \mathrm{ppm}$ reported by Leontopoulos et al. [16].

\subsection{Level of Iron [Fe]}

Prolong shortage of Fe will lead to the decrease in the amount of hemoglobin produced in the blood and consequently resulted to anaemia [17]. The enhanced absorption of $\mathrm{Cd}$ and $\mathrm{Zn}$ in cattle in contaminated areas has an adverse effect on $\mathrm{Fe}$ absorption [14]. This testifies to a considerable accumulation of $\mathrm{Fe}$ in intestinal organs. The concentration of iron $(\mathrm{Fe})$ in the liver, kidney and flesh showed no significant variation $(\mathrm{P}<0.05)$ among beef, mutton and caprine with the exception of liver and flesh samples from Bukkuyum. The result indicated that the 
Table 1. Concentration $\left(\mu \mathrm{g} \cdot \mathrm{g}^{-1}\right)$ of heavy metals in the liver of cattle, sheep and goat from Anka.

\begin{tabular}{ccccccccc}
\hline & $\mathrm{Zn}$ & $\mathrm{Fe}$ & $\mathrm{Pb}$ & $\mathrm{Mn}$ & $\mathrm{Cr}$ & $\mathrm{Cd}$ & $\mathrm{Co}$ \\
\hline Cattle & $549.255 \pm 0.003$ & $109.000 \pm 0.015$ & $\mathrm{ND}$ & $11.200 \pm 0.028$ & $1.400 \pm 0.018$ & $0.250 \pm 0.003$ & $0.525 \pm 0.045$ & $48.550 \pm 0.008$ \\
Sheep & $91.825 \pm 0.023$ & $190.150 \pm 0.025$ & $0.975 \pm 0.008$ & $13.250 \pm 0.005$ & $\mathrm{ND}$ & $0.125 \pm 0.008$ & $1.275 \pm 0.008$ & $149.300 \pm 0.020$ \\
Goat & $82.525 \pm 0.028$ & $375.100 \pm 0.015$ & $2.850 \pm 0.003$ & $6.900 \pm 0.018$ & $\mathrm{ND}$ & $0.125 \pm 0.008$ & $0.075 \pm 0.058$ & $231.900 \pm 0.010$ \\
\hline
\end{tabular}

The data are mean \pm standard deviation.

Table 2. Concentration $\left(\mu \mathrm{g} \cdot \mathrm{g}^{-1}\right)$ of heavy metals in the liver of cattle, sheep and goat from Bukkuyum.

\begin{tabular}{ccccccccc}
\hline & $\mathrm{Zn}$ & $\mathrm{Fe}$ & $\mathrm{Pb}$ & $\mathrm{Mn}$ & $\mathrm{Cr}$ & $\mathrm{Cd}$ & $\mathrm{Cu}$ & \\
\hline Cattle & $78.600 \pm 0.050$ & $322.450 \pm 0.013$ & $0.975 \pm 0.005$ & $11.725 \pm 0.0003$ & $0.850 \pm 0.008$ & $0.175 \pm 0.015$ & $2.175 \pm 0.050$ & $149.100 \pm 0.030$ \\
Sheep & $213.850 \pm 0.015$ & $273.650 \pm 0.008$ & $3.925 \pm 0.010$ & $13.100 \pm 0.015$ & $\mathrm{ND}$ & $0.200 \pm 0.010$ & $2.050 \pm 0.008$ & $538.425 \pm 0.018$ \\
Goat & $86.900 \pm 0.020$ & $158.700 \pm 0.015$ & $1.325 \pm 0.003$ & $13.025 \pm 0.008$ & $2.675 \pm 0.013$ & $0.175 \pm 0.013$ & $2.200 \pm 0.070$ & $144.350 \pm 0.018$ \\
\hline
\end{tabular}

The data are mean \pm standard deviation.

Table 3. Concentration $\left(\mu \mathrm{g} \cdot \mathrm{g}^{-1}\right)$ of heavy metals in the kidney of cattle, sheep and goat from Anka.

\begin{tabular}{ccccccccc}
\hline & $\mathrm{Zn}$ & $\mathrm{Fe}$ & $\mathrm{Pb}$ & $\mathrm{Mn}$ & $\mathrm{Cr}$ & $\mathrm{Cd}$ & $\mathrm{Cu}$ & \\
\hline Cattle & $55.525 \pm 0.018$ & $575.675 \pm 0.008$ & $\mathrm{ND}$ & $9.525 \pm 0.008$ & $0.475 \pm 0.015$ & $0.321 \pm 0.01$ & $0.675 \pm 0.008$ & $3.600 \pm 0.010$ \\
Sheep & $71.750 \pm 0.013$ & $306.550 \pm 0.005$ & $\mathrm{ND}$ & $6.000 \pm 0.010$ & $2.625 \pm 0.020$ & $0.175 \pm 0.013$ & $0.350 \pm 0.028$ & $4.300 \pm 0.008$ \\
Goat & $76.450 \pm 0.005$ & $335.275 \pm 0.010$ & $2.375 \pm 0.005$ & $7.900 \pm 0.005$ & $19.625 \pm 0.018$ & $1.100 \pm 0.003$ & $0.275 \pm 0.053$ & $16.300 \pm 0.0055$ \\
\hline
\end{tabular}

The data are mean \pm standard deviation.

Table 4. Concentration $\left(\mu \mathrm{g} \cdot \mathrm{g}^{-1}\right)$ of heavy metals in the kidney of cattle, sheep and goat from Bukkuyum.

\begin{tabular}{cccccccccccc}
\hline & $\mathrm{Zn}$ & $\mathrm{Fe}$ & $\mathrm{Pb}$ & $\mathrm{Mn}$ & $\mathrm{Cr}$ & $\mathrm{Cd}$ & $\mathrm{Cu}$ & $\mathrm{Cu}$ & & \\
\hline Cattle & $59.625 \pm$ & $334.050 \pm 0.008$ & $1.250 \pm 0.005$ & $6.975 \pm 0.018$ & $0.375 \pm 0.015$ & $0.200 \pm 0.008$ & $\mathrm{ND}$ & $15.975 \pm 0.003$ \\
Sheep & $99.575 \pm 0.025$ & $407.775 \pm 0.015$ & $3.100 \pm 0.010$ & $6.425 \pm 0.005$ & $0.300 \pm 0.018$ & $0.250 \pm 0.010$ & $2.625 \pm 0.085$ & $12.450 \pm 0.005$ \\
Goat & $75.325 \pm 0.030$ & $286.400 \pm 0.010$ & $1.900 \pm 0.005$ & $8.775 \pm 0.018$ & $3.750 \pm 0.013$ & $0.250 \pm 0.003$ & $2.275 \pm 0.023$ & $18.975 \pm 0.003$ \\
\hline
\end{tabular}

The data are mean \pm standard deviation.

Table 5. Concentration $\left(\mu \mathrm{g} \cdot \mathrm{g}^{-1}\right)$ of heavy metals in the flesh of cattle, sheep and goat from Anka.

\begin{tabular}{ccccccccc}
\hline Flesh & $\mathrm{Zn}$ & $\mathrm{Fe}$ & $\mathrm{Pb}$ & $\mathrm{Mn}$ & $\mathrm{Cr}$ & $\mathrm{Cd}$ & $\mathrm{Cu}$ & $\mathrm{Co}$ \\
\hline Cattle & $113.400 \pm 0.030$ & $304.250 \pm 0.010$ & $1.000 \pm 0.010$ & $6.775 \pm 0.008$ & $\mathrm{ND}$ & $0.025 \pm 0.003$ & $\mathrm{ND}$ & $5.950 \pm 0.013$ \\
Sheep & $75.225 \pm 0.045$ & $174.950 \pm 0.005$ & $\mathrm{ND}$ & $3.225 \pm 0.023$ & $0.225 \pm 0.010$ & $\mathrm{ND}$ & $1.200 \pm 0.050$ & $43.175 \pm 0.010$ \\
Goat & $94.075 \pm 0.038$ & $213.000 \pm 0.020$ & $2.975 \pm 0.003$ & $3.375 \pm 0.008$ & $\mathrm{ND}$ & $0.075 \pm 0.008$ & $0.675 \pm 0.075$ & $6.775 \pm 0.005$ \\
\hline
\end{tabular}

The data are mean \pm standard deviation.

Table 6. Concentration $\left(\mu \mathrm{g} \cdot \mathrm{g}^{-1}\right)$ of heavy metals in the flesh of cattle, sheep and goat from Bukkuyum.

\begin{tabular}{ccccccccc}
\hline Flesh & $\mathrm{Zn}$ & $\mathrm{Fe}$ & $\mathrm{Pb}$ & $\mathrm{Mn}$ & $\mathrm{Cr}$ & $\mathrm{Cd}$ & $\mathrm{Co}$ & $\mathrm{Cu}$ \\
\hline Cattle & $76.450 \pm 0.023$ & $200.800 \pm 0.008$ & $0.875 \pm 0.005$ & $5.625 \pm 0.013$ & $\mathrm{ND}$ & $0.100 \pm 0.003$ & $2.050 \pm 0.090$ & $2.575 \pm 0.1003$ \\
Sheep & $70.300 \pm 0.045$ & $166.900 \pm 0.010$ & $1.200 \pm 0.005$ & $2.525 \pm 0.003$ & $\mathrm{ND}$ & $0.100 \pm 0.008$ & $1.425 \pm 0.073$ & $161.225 \pm 0.048$ \\
Goat & $130.525 \pm 0.023$ & $146.425 \pm 0.005$ & $0.700 \pm 0.003$ & $3.350 \pm 0.008$ & $\mathrm{ND}$ & $0.125 \pm 0.008$ & $1.500 \pm 0.053$ & $7.850 \pm 0.000$ \\
\hline
\end{tabular}

The data are mean \pm standard deviation. 
kidney of cattle in Anka contained $575.675 \pm 0.008 \mu \mathrm{g} \cdot \mathrm{g}^{-1}$; the highest concentration of iron obtained, while goat flesh from Bukkuyum showed the lowest concentration of Fe $\left(146.425 \pm 0.005 \mu \mathrm{g} \cdot \mathrm{g}^{-1}\right)$. The highest concentration of Fe observed in the kidney of cattle from Anka may be due to the processing of the animal organ [14] [18]. The obtained results indicated that the animals reared in the area are good source of Fe. The results obtained were higher than the values 51.290 and $49.133 \mathrm{ppm}$ in cattle muscles reported by Korenekova et al. [19]. However, the values reported by this study were in agreement with the values 125.225 and $146.825 \mu \mathrm{g} \cdot \mathrm{g}^{-1}$ in the liver of cattle recorded by Korenekova et al. [19]. It is of interest that relatively well-balanced Fe levels were recorded in the two observed localities in the flesh and tissues of cattle, sheep and goat.

\subsection{Level of Lead [Pb]}

Acute toxicity of lead is not common except in a situation where one is exposed to high concentration of lead dust. This results to gastrointestinal upset, convulsion and stupor leading to suppressed immune response, lead nephritis a disease usually associated with mitochondrial damage in the renal tubules when blood levels are in excess of $150 \mathrm{ppm}$ [20]. Lead as observed in the liver of sheep from Bukkuyum in Table 2 showed the highest concentration of $3.925 \pm 0.010 \mu \mathrm{g} \cdot \mathrm{g}^{-1}$ and the lowest concentration of $0.700 \pm 0.03 \mu \mathrm{g} \cdot \mathrm{g}^{-1}$ in the flesh of goat from Bukkuyum as indicated in Table 6 . The values recorded by this study were higher than the values of $1.07 \mathrm{ppm}$ reported by Korenekova et al. [19] with the exception of kidney, liver of cattle, flesh and kidney of sheep samples from Anka where the $\mathrm{Pb}$ were not detected. $\mathrm{Pb}$ is known to accumulate mostly in the liver, while the high concentration of lead in the muscle indicates long term bioaccumulation [21]. The obtained results from this study revealed that concentration of lead in the kidney, liver and flesh of cattle, sheep and goat were higher than the permissible limit of $1 \mu \mathrm{g} \cdot \mathrm{g}^{-1}$ [13] with the exception of all flesh samples and kidney, liver of cattle and kidney of sheep from Anka were within the permissible limit. The higher concentration $\mathrm{Pb}$ observed in the liver of sheep from Bukkuyum may originate from contamination of feeds and water [11]. The results point to the fact that in the observed region, $\mathrm{Pb}$ acted as an important environmental contaminant in Bukkuyum, but in Anka it did not.

\subsection{Level of Copper [Cu]}

Copper is an essential components of various enzymes and it play a key role in the bone formation, skeletal, mineralization and in maintaining good health, but very high intake can cause health problems such as liver and kidney damage [22]. Copper can also cause public health hazard in high concentrations [23]. The highest copper concentration was found in the liver of sheep (Table 2) of $538.425 \pm 0.018 \mu \mathrm{g} \cdot \mathrm{g}^{-1}$ and the lowest value was observed in the flesh of cow $\left(2.575 \pm 0.00 \mu \mathrm{g} \cdot \mathrm{g}^{-1}\right)$. The copper concentration in the liver, kidney and flesh of cattle, sheep and goat were below the permissible limit of $200 \mu \mathrm{g} \cdot \mathrm{g}^{-1}$ [13] with the exception of liver of sheep in Table 2 and liver of goat in Table 3 that have 
content of copper respectively 538.425 and $231.900 \pm 0.010 \mu \mathrm{g} \cdot \mathrm{g}^{-1}$ which were higher than the permissible limit. The obtained results are higher than 0.4206 reported by Parekhan et al. [24].

\subsection{Level of Cadmium [Cd]}

Food is one of the principal environmental sources of Cd [25]. Cd predominantly accumulates in the kidneys and liver because its rate of elimination from these organs is relatively low [19]. This was partly due to the binding of Cd to metallothionein in these tissues [19]. Highest cadmium concentration was observed in the kidney of goat from Anka $1.100 \pm 0.003 \mu \mathrm{g} \cdot \mathrm{g}^{-1}$ (Table 3 ) and the lowest value $\left(0.075 \pm 0.008 \mu \mathrm{g} \cdot \mathrm{g}^{-1} \mathrm{ppm}\right)$ was in the flesh of goat from Anka (Table 5). The highest concentration of Cd observed in the kidney of goat from Anka may be originated from the processing of the organ [14]. From the results of this study, the concentration of cadmium in all the samples studied were found to be lower than the $0.5 \mu \mathrm{g} \cdot \mathrm{g}^{-1}$ permissible limit set by [26] with the exception of the kidney of goat from Anka which has the concentration of $1.100 \pm$ $0.003 \mu \mathrm{g} \cdot \mathrm{g}^{-1}$ (Table 3 ). The results point to the fact that in the observed region under study, Cd does not act as an important environmental contaminant. This indicates that the region is $\mathrm{Cd}$ free environment. The values recorded by this study were higher than the 0.126 ppm reported by Koronekova et al. [19].

\subsection{Level of Manganese [Mn]}

Daily intake of the small amounts of Mn is needed for growth and good health in humans, otherwise deficiency of Mn can cause nervous system problems [27]. Mn concentration was found to be highest in the liver of sheep from Anka $\left(13.250 \pm 0.005 \mu \mathrm{g} \cdot \mathrm{g}^{-1}\right)$ in Table 1 , while the least value was observed in the flesh of sheep from Bukkuyum $\left(2.725 \pm 0.003 \mu \mathrm{g} \cdot \mathrm{g}^{-1}\right)$ as indicated in Table 6. The concentration of $\mathrm{Mn}$ in all the samples were above $0.5 \mu \mathrm{g} \cdot \mathrm{g}^{-1}$ the permissible limit set by WHO [28]. The contaminated samples reported by this study were not in agreement with the values $4.11 \pm 0.44$ and $3.22 \pm 0.65 \mu \mathrm{g} \cdot \mathrm{g}^{-1}$ for liver of caprine and chicken respectively recorded by Akan et al. [15]. The contamination of all the samples with Mn may originate from processing of the animals organs [14] and mining activities [29].

\subsection{Level of Zinc [Zn]}

$\mathrm{Zn}$ is an essential element in human diet. Too little $\mathrm{Zn}$ can cause problems; however, too much $\mathrm{Zn}$ is harmful to human health [22] [30]. Zn concentration was found to be highest in the liver of cattle $549.255 \mu \mathrm{g} \cdot \mathrm{g}^{-1}$ (Table 1) while the lowest value in the flesh of sheep $\left(70.300 \pm 0.045 \mu \mathrm{g} \cdot \mathrm{g}^{-1}\right)$. The results obtained were higher than the values of $4.24 \pm 0.16$ and $2.34 \pm 0.08 \mu \mathrm{g} \cdot \mathrm{g}^{-1}$ for liver of beef and mutton reported by Akan et al. [15]. The concentrations of $\mathrm{Zn}$ in all the samples studied were below the permissible limit of $150 \mu \mathrm{g} \cdot \mathrm{g}^{-1}$ by [13] with the exception of liver of sheep from Bukkuyum (Table 2). The results point to the 
fact that in the observed region under study, $\mathrm{Zn}$ did not act as an important environmental contaminant.

\subsection{Level of Cobalt [Co]}

The major role of cobalt is an essential part of cobalamine or Vitamin $B_{12}$. In catthe and sheep, Cobalt deficiency causes inavailability of Vitamin $\mathrm{B}_{12}$ problems such as emaciation, anemia and restlessness. Cobalt concentration was found to be highest in the kidney of sheep $\left(2.625 \pm 0.085 \mathrm{~g} \cdot \mathrm{g}^{-1}\right)$ from Bukkuyum lowest in the kidney and flesh of cattle from Anka and Bukkuyum in Table 4 and Table 5 respectively. The highest concentration of Co observed in the kidney of sheep from Bukkuyum may be originated from the processing of the organ [14]. The concentrations of Co reported by this study were higher than the values of $0.23 \pm$ 0.04 and $0.56 \pm 0.05 \mu \mathrm{g} \cdot \mathrm{g}^{-1}$ for the kidneys of beef and mutton recorded by [15] and the values seems to agree with each other. The values were generally lower than the $3.4 \mathrm{ppm}$ wet mass reported by FAO [31]. The concentration of Co in all the samples were above the standard limit of $0.5 \mu \mathrm{g} \cdot \mathrm{g}^{-1}$ set by the European Commission EC [32] with the exception of 6 samples where the concentration of Co is lower than the standard limit. The results indicate that the region under study was contaminated with Co as an environmental pollutant [33].

\section{Conclusions}

From the results of this study, the concentrations of all the heavy metals in the liver, kidney and flesh of beef, mutton and caprine were found to be statistically not significant $(\mathrm{P}<0.005)$. Generally, livers and kidneys were found to have the highest significant levels of metals and flesh the lowest levels. When compared to one another beef, mutton and caprine, show no significant differences in the levels of heavy metals content. The concentration of all the metals in the flesh samples was within the tolerance limits with the exception of $\mathrm{Pb}$ and $\mathrm{Mn}$ content in the flesh of goat and sheep in Anka and Bukkuyum respectively was higher than the ANZFA limits [13].

The concentration of some of the trace metals in the kidneys and livers samples analyzed such as $\mathrm{Zn}, \mathrm{Cd}$, Co and $\mathrm{Cu}$ were also observed to be within the tolerance limits with the exception of $\mathrm{Zn}$ in Kidney of sheep from Anka, Cd in kidney of goat from Anka and $\mathrm{Cu}$ in the liver of goat from Bukkuyum and sheep from Anka.

The concentration of $\mathrm{Cr}, \mathrm{Pb}$ and $\mathrm{Mn}$ in the kidneys and livers samples was observed to be higher than the standard limit with the exception of $\mathrm{Cr}$ in the liver of sheep and goat from Anka and liver of sheep from Bukkuyum, $\mathrm{Pb}$ in some liver and kidney samples and Mn in some liver, kidney samples and flesh of cattle from Anka.

\section{Conflicts of Interest}

The authors declare no conflicts of interest regarding the publication of this paper. 


\section{References}

[1] Alloway, B.J. (1990) Heavy Metals in Soils. John Wiley and Sons, Inc., New York, 25-36.

[2] Guthrie, A.H. (1989) Introductory Nutrition. 7th Edition, Times Mirror/Mosby College Publishing, St. Louis, 289-331.

[3] Liver, A.B.P. (1981) Coordination Chemistry Reviews. Elsevier Scientific Publishing Company, Amsterdam, 167-175.

[4] Ojeka, O.E. and Iyodele, T.J. (1997) Determination of Selected Heavy metal level Infant Milk Products in Nigerian Market. Nigerian Journal of Technical Education, 14, 167-175.

[5] Sabir, S.M., Khan, S.W. and Hayat, I. (2003) Effect of Environmental Pollution on Quality of Meat in District Bagh, Azad Kashmir. Pakistan Journal of Nutrition, 2, 98-101. https://doi.org/10.3923/pjn.2003.98.101

[6] SCAN (2003) Scientific Committee on Animal Nutrition: Opinion of the Undesirable Substances in Feed. http://Europa.Eu.In/comm/food/fs/sc/scan/out126bisen.Pdf

[7] Hertz, W. and Kostial, K. (1986) Trace Elements in Human and animal Nutrition. 5th Edition, Academic press, Orlando, 319-345.

[8] Goyer, R.A. (1996) Toxic Effects of Metals. In: Klassen, C.D., Ed, Casarret and Doulls Toxicology: The Basic Science of Poisons, 5th Edition, McGraw-Hill Health Professional Division, New York.

[9] Lopez, A.M., Bento, J.L., Miranda, J.L., Castillo, M., Hernendez, J. and Shore, R.F. (2002) Cattle as Biomonitor of Soil Arsenic, Copper and Zinc Concentrations in Galacia North Western Spain. Archives of Environmental Contaminants and Toxicology, 43, 103-108. https://doi.org/10.1007/s00244-002-1168-5

[10] Blacksmith Institute (2010) Papers and Annual Report. New York, NY.

[11] Iwegbue, C.M., Nwajei, G.E. and Iyoha, E.H. (2008) Heavy Metal Residues of Chicken Meat and Gizzard and Turkey Meat Consumed in Southern Nigeria. Bulleting of Veterinary Medicine, 11, 275-280.

[12] Institute of Medicine (2002) Dietary Reference Intakes for Vitamin, A and Vitamin K, Arsenic, Boron, Vanadium, Chromium, Copper, Iodine, Iron, Manganese, Molybdenum, Nickel, Silicon and Zinc. Institute of Medicine of the National Academics, Washington DC.

[13] ANZFA (2001) Australia New Zealand Food Authority Wellington NZ 6036 May, 2001. http://www.anzfa.gov.au

[14] Raikwar, M., Kumar, P., Singh, M. and Sigh, A. (2008) Toxic Effect of Heavy Metals in Livestock Health. Veterinary World Journal, 1, 28-30. https://doi.org/10.5455/vetworld.2008.28-30

[15] Akan, J.C., Abdulrahman, F.I., Sodipo, O.A. and Chiroma, Y.A. (2010) Distribution of Heavy Metals in the Liver, Kidney and Meat of Beef, Mutton, Caprine and Chiken from Kasuwan Shanu Market in Maiduguri Metropolis, Borno State, Nigeria. Research Journal of Applied Science, Engineering and Technology, 2, 743-748.

[16] Leontopoulos, S.T., Gougoulias, N., Kautas, D., Roka, L. and Makridis, C.H. (2015) Accumulation in a Animal Tissues and Internal Organs of Pigs Correlated with Feed Habits. Technological Educational Institute of Thessaly, Department of Agronomy Technology, Larissa, Laboratory of Molecular Biology, Agricultural University of Athens, Athens.

[17] Charles, A. and Guy, L. (1999) Food Biochemistry. Aspen Publishers, Gaithersburg, 
15.

[18] Santhi, D., Balakrishnan, V., Kalaikannan, A. and Radhakrisshnan, K.T. (2008) Presence of Heavy Metals in Pork Products in Chennai (India). American Journal of Food Technology, 3, 192-199. https://doi.org/10.3923/ajft.2008.192.199

[19] Korenekova, B., Skalika, M. and Nad, P. (2002) Concentration of Some Heavy Metals in Cattle Reared in the Vicinity of Metrological Industry. Veterinary Archive, 72, 259-267.

[20] Hayes, J.A. (1989) A Guide to General Toxicology. 2nd Revised Edition, Kargar Continuing Education Series, Vol. 5, 179-188.

[21] Oforka, N., Osuji, L. and Onwuachu, U. (2012) Assessment of Heavy Metal Pollution in Muscles and Internal Organs of Chickens Raised in Rivers State, Nigeria. Journal of Emerging Trends in Engineering and Applied Science, 3, 406-411.

[22] ATSDR (2004) Agency for Toxic Substances and Diseases Registry. Division of Toxicology, Atlanta. http://www.atsdr.cdc.gov/toxprofiles

[23] Brito, G., Diaz, C., Galindo, L., Hardisson, A., Santiago, D. and Garcia, M.F. (2005) Levels of Metals in Canned Meat Products: Intermetallic Correlations. Bulleting of Environmental Contaminants and Toxicology, 42, 309-316. https://doi.org/10.1007/BF01700152

[24] Aljaff, P., Rasheed, B.O. and Salh, D.M. (2003) Assessment of Heavy Metal in Livers of Cattle and Chicken. Journal of Applied Physics, 6, 23-26.

[25] Baykov, B.D., Stoyanor, M.P. and Gugover, M.L. (1996) Cadmium and Lead Bioaccumulation in Male Chickens for Higher Food Concentration. Toxicology and Environmental Chemistry, 54, 155-159. https://doi.org/10.1080/02772249609358308

[26] FAO/WHO (2000) Report of the 32nd Session of the Codex Committee of the Food Additives Contaminants. Beijing.

[27] Demirezen, D. and Uruc, K. (2006) Comparative Study of Trace Elements in Certain Fish, Meat and Product. Meat Science, 74, 255-260. https://doi.org/10.1016/j.meatsci.2006.03.012

[28] WHO (2000) Codex Committee of the Food Additives Contaminants. Beijing.

[29] Navarro, M.C., Perez-Sirvent, M.J., Videl, J., Tovar, P.J. and Bech, J. (2008) Abandoned Mine Sites as a Source of Contamination by Heavy Metals: A Study in Semi-Arid Zone. Journal of Geochemical Exploration, 96, 183-193. https://doi.org/10.1016/j.gexplo.2007.04.011

[30] McBride, M.B. and Spiers, G. (2001) Trace Element Content of Selected Fertilizers and Dairy Manures as Determined by ICP-MS. Soil Science and Plants Analysis, 32, 139-156. https://doi.org/10.1081/CSS-100102999

[31] FAO (2006) UN Food and Agricultural Organization. Food Composition in Terms of $100 \mathrm{~g}$ Edible Portion.

[32] EC (2001) European Commission, the Soil Protection Communication DG Environmental Draft.

[33] Wentink, G.H., Wensing, G.G. and Kessels, F. (1992) Toxiciterit Van Cadmium Voor Rundvee. Jijd school Of Diergoneesk, 17, 548-550. 